C. K. M. Mak $\cdot$ V. K. L. Hung $\cdot$ J. T. Y. Wong

\title{
Type II topoisomerase activities in both the G1 and G2/M phases of the dinoflagellate cell cycle
}

Published online: 12 April 2006

C) Springer-Verlag 2006

\section{Chromosoma (2005) 114: 420-431}

Owing to an unfortunate oversight, the Acknowledgement section was omitted and is now printed below.

Acknowledgement The present study was partly supported by a grant (HKUST6244/04M) from the Research Grant Council of the Government of Hong Kong SAR to JTYW.

The online version of the original article can be found at http://dx.doi.org/10.1007/s00412-005-0027-3

C. K. M. Mak · V. K. L. Hung · J. T. Y. Wong $(\bowtie)$ Biology Department, Hong Kong University of Science and Technology, Clearwater Bay,

Kowloon, Hong Kong SAR, People's Republic of China e-mail: botin@ust.hk

Tel.: $+852-23587343$

Fax: $+852-23581559$ 